\title{
Utilization of robusta coffee waste as a renewable energy material - bioetanol
}

\author{
Sutarno*, Abdul Malik Kholiq \\ Department of Chemical Engineering Faculty of Industrial Technology Indonesian Islamic University \\ Jl. Kaliurang Km 14.5 Sleman - Yogyakarta, Indonesia
}

\begin{abstract}
A research on robusta coffee waste has been conducted as a renewable energy material Bioethanol. This research was carried out by hydrolysis and fermentation process using Zymomonasmobilis and Saccharomyces cerevisiae (Zymomonasmobilis) bacteria to obtain the best catalyst type in the process of hydrolysis of coffee skin to glucose and the effect of fermentation time on bioethanol content produced. This research was conducted by varying the fermentation time of 7 days; 8 days; 9 days and 10 days. The fermentation fluid was then distilled and tested for bioethanol using a refractometer. Furthermore, bioethanol concentration in the analysis using.
\end{abstract}

\section{Preface}

Currently high energy consumption is not comparable with the availability of fossil energy sources (especially petroleum) is increasingly depleted. Sooner or later the world's oil reserves will be exhausted. This is due to its limited availability and non-renewable. Therefore, it takes alternative energy that can be used as a substitute for fossil energy. Research on renewable energy continues to be developed, even becoming one of the important programs of various countries to reduce dependence on oil energy that its availability continues to decline. One product that allows to be developed is bioethanol that can be used as fuel for solving energy problems today.

Bioethanol has several advantages over other renewable energies. Among them have higher oxygen content $(35 \%)$ so that it burns more perfectly, octane is higher (118), and more environmentally friendly because it contains lower exhaust emissions $19-25 \%$. In addition, the substrate for bioethanol production is quite abundant in Indonesia. This product is expected to be able to replace the fuel oil of motor vehicles and industrial machinery. In addition, bioethanol can be produced in microorganisms continuously [2].

One example of material that can be used to produce ethanol is robusta coffee waste that is widely available in rural Indonesia. The production of coffee processing involves a number of byproducts after the coffee beans undergo the grinding process using a traditional machine or tool. In the process, between the skin of the shell and the coffee beans will be separated. If the mill uses the machine and is done in the factory, it is generally not used and accumulates as a by-product of the grinding process. This skin is mostly waste and will be disposed of or used as animal feed so it takes effort to process this waste into bioethanol as renewable energy.

\section{Research Methods}

The material used is robusta coffee leather waste obtained from farmers of Cangkringan village slopes of Mount Merapi in Sleman district of Yogyakarta. Aquadest, $\mathrm{HCl}$, $\mathrm{NaOH}$, sugar, Saccharomyces cereviseae, and Zymomonas mobilis purchased at UGM Faculty of Biology Laboratory Yogyakarta and Urea purchased in one shop in Yogyakarta city. The tools used are hydrolysis, fermentation and distillation apparatus

\subsection{Raw Material Preparation}

Clean the coffee peel from the dirt, dry it with oven at 100 ${ }^{\circ} \mathrm{C}$ for 2 hours. Then break the skin of the coffee by blending / milling to form a powder, sift the skin of coffee on the sieve 80 mesh and analysis of cellulosanya content with spectrophotometer.

\subsection{Hydrolysis process}

Weigh the powder of 100 grams of coffee skin. Add aquadest and acid catalyst according to the variable that is run $\mathrm{H}_{2} \mathrm{SO}_{4}$ and $\mathrm{HCl}$ with volume ratio $10,20,30 \% \mathrm{v} / \mathrm{v}$ until total of 1 liter solution. Enter into the hydrolysis flask and hydrolysis with a temperature of $100{ }^{\circ} \mathrm{C}$ for 4 hours. Filter the solution of hydrolysis and filtrate taken to be analyzed its glucose level with spectrophotometer.

\subsection{Fermentation Process}

Take the filtrate from the hydrolysis process of $500 \mathrm{ml}$ and add $\mathrm{NaOH} 1 \mathrm{~N}$ to $\mathrm{pH}=6$. Sterilize in autoclave at $120^{\circ} \mathrm{C}$ for 15 minutes. Chill to room temperature. Enter starter 
Zymomonasmobilis with variable: starter volume 9, 10, $11 \% \mathrm{v} / \mathrm{v}$ and shuffled. Cover the fermented bottle until tightly and the gas is flowed into another bottle containing the water. Fermentation according to fermentation time variables are 2, 3, 4, 5, 6 and 7 days with fermentation temperature $30{ }^{\circ} \mathrm{C}$. Filter and take filtrate for distillation process.

\subsection{Distillation Process}

The fermented filtrate was distilled at $80{ }^{\circ} \mathrm{C}$ to obtain higher levels as desired and then analyzed the ethanol content.

\section{Results and Discussion}

\subsection{Hydrolysis process}

Hydrolysis process is the process of solving complex compounds into simple compounds with the help of water. The first treatment of hydrolysis of coffee skin powder is done with acid, ie $\mathrm{HCl} 1 \mathrm{~N}$ solution. $\mathrm{HCl}$ which is a strong acid will tend to give protons if dissolved in water, so this acid will change entirely into base pair / conjugate. $\mathrm{HCl}$ solution will hydrolyze the coffee skin powder through a chain-cutting process which results in cellulose/glucose.

This process was performed using 4 (four) samples each weighing 100 grams, using a varied $\mathrm{HCl} 1 \mathrm{~N}$ catalyst that is $250 \mathrm{ml}, 300 \mathrm{ml}, 350 \mathrm{ml}$ and $400 \mathrm{ml}$. This hydrolysis process is carried out for 4 hours of each sample at a temperature of $100{ }^{\circ} \mathrm{C}$. The temperature selected in this study is relatively high, because in the process of hydrolysis using acid catalysts require very high temperatures for the hydrolysis process can occur.

Selected $\mathrm{HCl}$ catalysts due to $\mathrm{HCl}$ produce higher glucose when compared with $\mathrm{H}_{2} \mathrm{SO}_{4}$. This is because $\mathrm{H}_{2} \mathrm{SO}_{4}$ is cellulose while $\mathrm{HCl}$ is not, so the resulting glucose levels are less.

Hydrolysis by using acid will produce a more tenuous structure, so water is more volatile at the time of drying. The powdered structure of the coffee powder is densely packed to be higher in water holding capacity and there is a breaking of the hydrogen bonding bonds in the linear chain.

Variations in the number of $\mathrm{HCl} 1 \mathrm{~N}$ catalysts used were intended to compare the cellulose content of coffee skin powder. The best catalyst was used in the concentration of catalyst $\mathrm{HCl} 1 \mathrm{~N} 20 \%$ (v/v).

In the process of acid hydrolysis, the $\mathrm{H}+$ group of $\mathrm{HCl}$ will convert the cellulose group from the coffee skin powder to the free radical group. The free radical group will then bind to $\mathrm{OH}$ from water and will react to produce glucose. In this study, the higher the concentration of $\mathrm{HCl}$ used with the same hydrolysis time is 4 hours, then the resulting glucose level higher. This happens because the free radical groups of cellulose powder of coffee skin produced more and more, so that glucose produced maximum. However, in this study the results obtained glucose is not too high due to several factors, namely the presence of lignin in the coffee, the hirolisa temperature Unstable and calculation of tools and materials used.

Thus, hydrolysis of coffee skin powder with optimum results using $\mathrm{HCl} 25 \%$ for 4 hours that produce glucose as much as $11.02 \%$. The results of each sample will then be fermented to ensure that the filtrate can be used as a fermentation substrate which, when fermented, can produce ethanol.

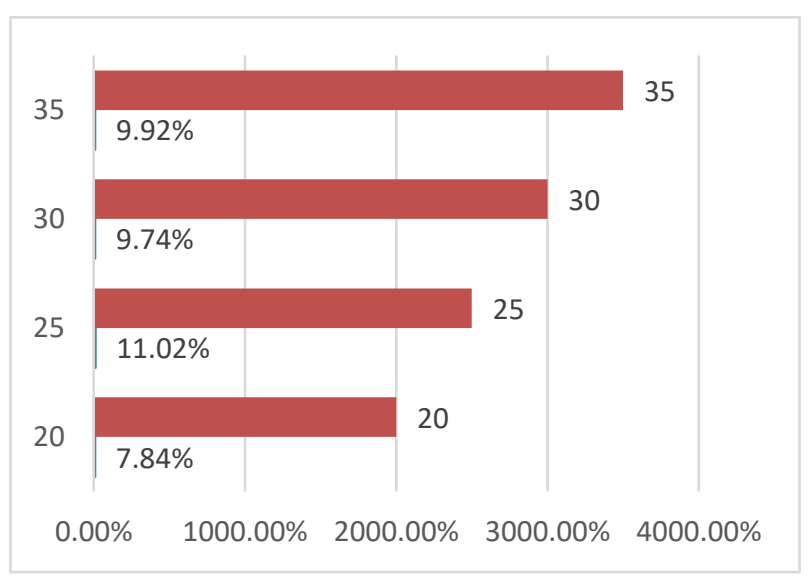

Fig. 1. Analysis of glucose levels in Robusta coffee

\subsection{Fermentation Process}

The process of fermentation of sugar from coffee skin hydrolysis to bioethanol using Zymomonasmobilis bacteria and Saccharomyces cerevisiae. The optimum temperature of the fermentation process using Zymomomobilis is in the $\mathrm{pH}$ range of 4-7.

The purpose of this research is to find the best catalyst type in the process of hydrolyzing the coffee skin into glucose and to find the fermentation time in the process of fermentation of glucose from coffee skin to ethanol.

The fermentation process takes place between 7 days; 8 days; 9 days and 10 days. The experimental results of the effect of fermentation time on bioethanol concentration are shown in Fig. 1. Without additional yeast support, fermentation is able to change the sugar content present in coffee coffee leaf waste. However, the 24-hour fermentation will not be perfect. Imperfect fermentation without yeast, caused by 2 things i.e.; First, in the open air there are spores of yeast Saccharomyces cerevisiae. But the population, certainly not as much when specifically mixed in the results of pulping the coffee fruit. Secondly, in the open air there is also Acetobacter aceti bacteria that will convert sugar into acetic acid. With the active bacteria Acetobacter aceti, the yeast Saccharomyces cerevisiae will be pressed and not developed so that fermentation is not running perfectly. With the help of yeast, precisely Acetobacter bacteria are pressed, and not developed. Because the rise of one yeast population, will inhibit the growth of other types of bacteria (fermentation process in coffee beans, 2011). Fermentation with the help of yeast will shorten the time. Research conducted by Siswati on coffee skin waste has a completely different result with the results of this study. The longer the fermentation time the higher the resulting ethanol content [7]. 
The relationship between the length of time of fermentation with the ethanol content produced is also linear, the longer the fermentation time is used then the ethanol content produced is also linear, since the fermentation time is influenced by the sugar concentration, the culture used and the fermentation temperature [6]. The best fermentation time used was for 7 days resulting in ethanol content of $67.99 \%$, and on days 8 to 10 showed a decrease in ethanol content of $44.85 \%$, $38.96 \%$ san $43.30 \%$. The imperfect fermentation results due to the spores of yeast Saccaromyces cereviseae and Acetobacter aceti bacteria that will convert sugar to acetic acid. With the Acetobacter aceti bacteria, the Asacharomyces cereviseae bacteria will be pushed and not fully developed.

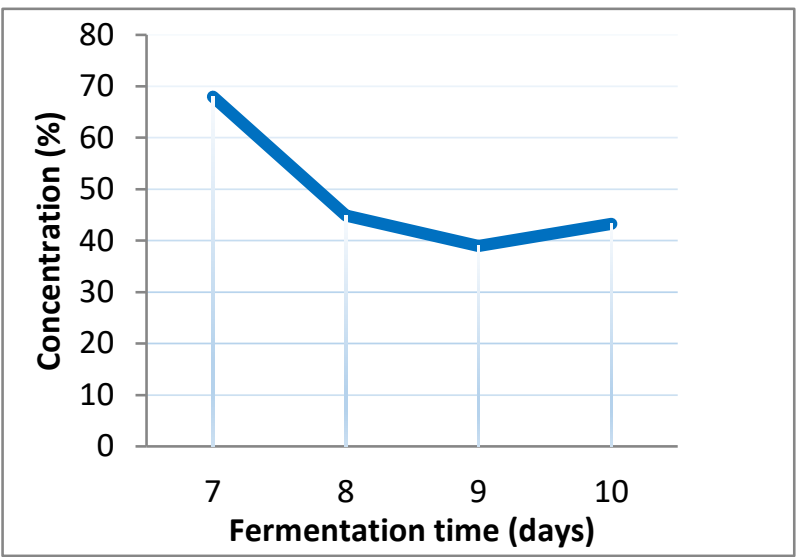

Fig. 2. Graph of the relationship between fermentation time and ethanol content produced

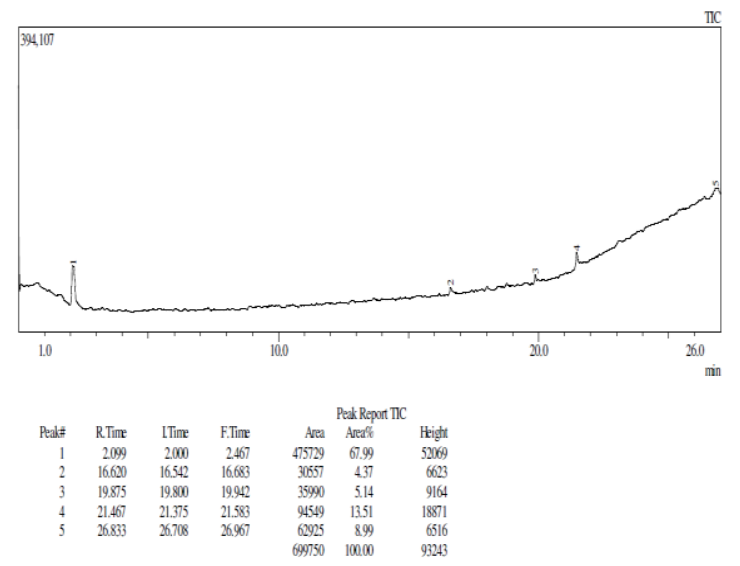

Fig. 3. Graph of bioethanol obtained from GCMC analysis

The result of GCMC analysis in Figure 3 shows that the bioethanol obtained at Retention Time (RT) 2.099 minutes is $67.99 \%$.

\subsection{Distillation Process}

The result of fermentation of each filtered and filtrate sample is not through the next step, that is the distillation process to get the ethanol produced because most likely the ethanol produced from the fermentation process will evaporate and run out if heated.

\subsection{Bioethanol produced}

Based on fermentation process for 7 days resulted bioetnol with ethanol content equal to $67,99 \%$, and on day 8 until 10 showed decrease of ethanol content equal to $44,85 \%, 38,96 \%$ and $43,30 \%$.

\section{Conclusion}

The results of this study can be concluded that the skin of coffee can be used as an alternative raw material of bioethanol production by hydrolysis and fermentation process. Coffee skin contains $50.03 \%$ cellulose, after hydrolyzed using $\mathrm{HCl} 1 \mathrm{~N}$ with varying volume ratio yielding the highest glucose level of $11.02 \%$ with $25 \%$ $\mathrm{HCl}$ level.

In this study, in the fermentation process using 2 (two) bacteria, the bacteria Saccharomyces cereviseae and zymomonas mobilis. The use of these two bacteria to make the fermentation process faster.

Result of ethanol analysis from fermentation filtrate, yielding ethanol level of $67,99 \%$ at 7 th day fermetation and on day 8 until 10 showed decrease of ethanol content equal to $44,85 \%, 38,96 \%$ san $4330 \%$. The imperfect fermentation results due to the spores of yeast Saccaromyces cereviseae and Acetobacter aceti bacteria that will convert sugar to acetic acid. With the Acetobacter aceti bacteria the Asacharomyces cereviseae bacteria will be pushed and not developed perfectly.

The study was assisted by Eka Riska Khailani, Eida Ocvita, and Fappy Sofhia Ratnasari, published in laboratory research. All three are alumni of Chemical Engineering UII Yogyakarta. In connection with that, the authors say thank you.

\section{References}

1. N. Azizah, et al. The Effect of Old Fermentation on Alcohol Levels, Ph, And Gas Production In The Fermentation Process Of Bioethanol Whey With Pineapple Skin Substitution. J. Appl. FT, 1, 2, (2012).

2. Z. Efendi, L. Treasures, Nutritional content of fruit coffee fermentation : Case Study of Water Village Meles Beb Sub Curup Timur Subdistrict, J. BPTP Bkl, (2014).

3. G. Arasyid et al (2016). Hydrolysis Processes for Ethanol from Lignosellulosic Material : A Review, Bioresources 2, 3, 472-499, (2016).

4. Hapsari, M. Amalia, A. Pramashinta. Making Bioethanol from Cassava Rubber (Manihot glaziovii) for Household Stove Fuel as Efforts to Accelerate Conversion of Kerosene to Biofuels. J. CIT, 2, 2. (2013).

5. Y. Indartono, Bioethanol, Alternative Renewable Energy: Achievement Study Machinery and Implementation in the field Physics, LIPI., (2005)

6. M. Judoamidjoyo, A.a. Darwis and E.G.Said, Fermentation Technology. Jakarta: Rajawali Press. (1982). 
7. N.D. Siswati, Yatim, M. Hidayanto, R, Bioetanol from Waste Leather Coffee with S.M. Lee, Y.M. Koo, Pilot scale production of cellulose using Trichoderma reesei Rut C-30 in fed-batch mode. J. M B.11: 229-233 (2001).

8. J. Mohammad, Taherzadeh, K. Karimi. Enzymebased Hydrolysis Processes for Ethanol from Lignocellulosic Materials : A review. (2007).

9. Widyotomo, Sukrisno. Potential And Technology Of Coffee Waste Diversification Become Quality And Value Added Products. Review of Coffee and Cocoa Research 1 (1) 2013, pp. 63-80. (2012).

10. Wignyanto, et al. Effect of Sugar Reducer Pineapple Reduction Concentration and Saccharomyces Cerevisiae Inoculum On Ethanol Fermentation. J. AT, 2, 1, pp. 68-77 (2001).

11. S. Onuki. Bioethanol: Industrial Production Process and Recent Studies. Iowa State University. Department of Agricultural and Biosystems Engineering, (2007).

12. S.M. Lee, Y.M. Koo. Pilot scale production of cellulose using Trichoderma reesei Rut C-30 in fedbatch mode. J. MB..11: 229-233. (2001).

13. Komarayati, Sri, Gusmailina. Bioethanol Prospect as a Substitute Kerosene. Bogor: Center for Research and Development of Forest Products. (2010).

14. Raudah, Ernawati. The Use Of Arabica Coffee Skin From The Pulping Process For Making Bioethanol. J. S T, Department of Chemical Engineering, State Polytechnic of Lhokseumawe 10. 21, (2011). 